\title{
Challenges in Education Research in Taiwan: Research Institutes and Organizations, Research Policies, and Problems
}

\author{
Jia Li Huanga,* \\ ${ }^{a}$ National Taiwan Normal University, Taiwan
}

\begin{abstract}
Since the 1990s, many education researchers and policy makers worldwide have reviewed education research to attempt to provide strategies to improve the quality of such research in their countries. Taiwan's government has launched policies and funded support to set the benchmark for Taiwan's leading universities in international academic competition. The external environment of global competition based on research policy influences the ecosystem of social science research production. To assure the quality of education policy, peer review from within the education community is one approach to supplementing the government's governance, including the establishment of research institutes, promotion, rewards, and research value. This study tracked the mode of academic research and provides an overview of the status of academic education research in Taiwan. Because education research is part of the humanities and social sciences fields, this study identified the challenges in educational research by examining the trend of social science research and by analyzing research organizations, policy, and the evaluation of research performance. Due to the environment of education research in Taiwan is not friendly to education researcher to accumulate papers in SSCI or international journal, additional concerns entail how education research communities can develop and agree on its quality.
\end{abstract}

\begin{abstract}
Abstrak
Sejak tahun 1990-an, pembuat kebijakan dan peneliti pendidikan di seluruh dunia telah melakukan kajian tentang penelitian pendidikan, guna menggali strategi perbaikan kualitas riset di negara mereka. Pemerintah Taiwan mengeluarkan kebijakan dan dukungan finansial demi kemajuan penelitian universitasuniversitas unggul di Taiwan di kancah akademik internasional. Kompetisi penelitian pendidikan global sebagai faktor ekstenal jelas mempengaruhi ekosistem pertumbuhan riset ilmu sosial. Untuk menjamin kualitas kebijakan pendidikan, salah satu pendekatannya adalah dengan melakukan peer-review atau penelaahan hasil penelitian oleh sesama kolega dalam komunitas pendidikan, selain dari upaya-upaya insentif pemerintah, seperti pendirian lembaga riset, promosi, hibah, dan pembobotan penelitian. Makalah ini membahas pendekatan penelitian akademis dan gambaran umum kondisi penelitian pendidikan di Taiwan. Karena pendidikan adalah bagian dari ilmu sosial dan humanitas, makalah ini juga mengidentifikasi kendala-kendala penelitian pendidikan dengan menganalisa tren penelitian ilmu sosial, lembaga penelitian, kebijakan terkait dan evaluasi hasil penelitian. Dikarenakan lingkungan riset pendidikan di Taiwan kurang terbuka kepada para peneliti, terutama untuk pengumpulan makalah di SSCI atau jurnal internasional, maka juga perlu dipikirkan bagaimana komunitas penelitian pendidikan dapat tumbuh dan mengembangkan kualitasnya.
\end{abstract}

Keywords: Research Policy, Research Organizations, Research Performance, Promotion, Tenure, Taiwan

\section{Background}

The quality of education research is crucial to education practice. The outcome of education research functions to improve educational practice and direct the trend of educational innovation. However, these goals depend on the quality of educational research. Since the 1990s, the relationship between education research and policy has been discussed continually worldwide. Examples include

*Corresponding author. Address: National Taiwan Normal University, Taiwan. Email: carriehng0802@gmail.com. the United Kingdom (UK) Hillage Report, entitled "Excellence in Research on School," by Jim Hillage and colleagues (1998) for the

(ec) BYANC-ND 
then Department for Education and Employment, and "Education Research: A Critique" by James Tooley and Doug Darby (1988) for the UK Office for Standards in Education. These debates on the broken and unreliable research-policy relationship in the UK have been paralleled with similar debates in the United States (US). Since the No Child Left Behind Act of 2001 and the Education Sciences Reform Act of 2002, the US government specifically sought high-quality scientific work in which randomized field trials or experimental designs were used for policy and practice decisions (Desimone and Le Floch 2004), which had been relatively lacking in education research. For instance, in the UK and the US, the quality of education research influences the status of social imagination in education research practice and affects the value of education policy application. Clearly, the value of education research in evaluation standards set by government seems more negative than positive.

Research is one of the fundamental functions of universities, and the researcher ratio from universities is 91.2 percent, which was the highest proportion in Taiwan for 2009 (National Science Council [NSC] 2011a). Because higher education is regarded as critical to international competitiveness and individual opportunity, its quality and status have become crucial indicators (Hazelkorn 2009). The increasing competition for global university rankings has altered the academic governance of universities by introducing external academic evaluation. Many governments, including the Taiwanese government, have launched policies and funded support to establish the benchmark for Taiwan's leading universities in international academic competition (Chou, Lin, and Chiu 2013). The indicators of academic or research performance used in evaluating research quality are included in frequently cited articles published in leading scientific journals. Even if the global ranking of higher education institutions has been perceived as a lack of sufficient comparative information on higher education (Hazelkorn 2009), the external environment of global competition emphasizes how research quality influences the ecosystem of social science research production, particularly when the outcomes of education research are questioned.

A high emphasis on ranking and research quality from the external environment demands additional requirements of rigor, objectivity, and peer review of research. Coupled with the external environment, the definition of education research quality being used of the reward, personal promotion, and pay by merit leads to the trend of assessing research value. Featherstone (1993) stated, "One paradoxical consequence of the process of globalization, the awareness of the finitude and boundedness of the plane of humanity, is not to produce homogeneity, but to familiarize us with greater diversity, the extensive range of local cultures" (p. 163). This paper provides an overview of the condition of academic education research in Taiwan. Taiwan was used as a sample case in the environment of edu- cation research and evaluated to provide a reference for other countries when discussing education research quality in the context of policy practice. The environment of education research included academic organizations and institutions, research policies launched by governments, and problems experienced by education researchers in Taiwan, according to document and literature analysis.

\section{Educational Research Organizations in Taiwan}

The NSC and Academia Sinica are the chief agencies responsible for allocating Taiwan's budget for basic scientific research. The NSC was established on 1 February 1959 as a dedicated agency for the government to promote the development of science and technology. The NSC, as the essential grant funding authority, has not changed, even when the organization has been adjusted according to the needs of the changing social environment. Education is categorized as a division of the social sciences field in the Department of Humanities and Social Science of the NSC. Other subjects include psychology, sociology, law, political science, area studies, economics and management science, and other social science disciplines. In March 2014, the NSC was transformed into the Ministry of Science and Technology (MoST), inheriting the original function of the NSC.

The most preeminent academic institution in Taiwan, Academia Sinica, was founded in 1928 to promote and undertake scholarly research in the sciences and humanities. Although Academia Sinica has not established a research institute or research center in the educational field, it has assumed a leadership role in launching new initiatives in applied areas to meet a broad spectrum of social needs in Taiwan. One of the missions of Academia Sinica is to plan the national academic research guidelines in the regulation of the Academia Sinica Organization Act. Academia Sinica is Taiwan's highest academic research organization and has a high academic reputation and a solid research foundation. The organization is dedicated to developing innovative scientific knowledge and offers efficient policy advice. The main responsibilities of Academia Sinica include conducting humanities and scientific research, encouraging academic research, and cultivating academic research talent. Each institute or research center at Academia Sinica sets research focuses and recruits talent on the basis of its academic development directions and conducts research independently (NSC 2011). Despite the education research institute was not established in Academia Sinica, the status of education research is still not high in Taiwan, which affects education research in the competition for awards, grants, funds, and other advantages.

According to the two central academic research institutions in Taiwan, the funding or project grants for education research mainly come from the NSC (Tien 2007a). To summarize the development 
of academic research in Taiwan, the NSC has annually published the "Yearbook of Science and Technology, Taiwan, ROC." The yearbook provides a comprehensive overview of Taiwan's policies and measures in science and technology (S\&T) development as well as research achievements in S\&T from the industrial, governmental, and academic sectors since 1983. The yearbook serves as a means for the government to understand S\&T development trends and to formulate S\&T policies for the future.

Another institution closely associated with education research is the National Academy for Educational Research (NAER), which was established in 2011 and enacted by the NAER Organization Act. The NAER took 10 years to integrate the Taiwan Provincial Institute for Elementary School Teachers Training Service, Taiwan Provincial Institute for Secondary School Teachers Training Service, National Institute of Translation and Compilation, and National Institute of Educational Resources and Publishing. According to the function of the original institute, the NAER serves as the education policy think-tank as a research institute at the national level and is responsible for long-term, integrated, and systematic research, offering the results as a reference for the government to develop related policies. In addition, on the specialization of testing, assessment, and curriculum development, the NAER develops student databases, compiles textbooks, and manages the certifying of teacher qualifications. Along with its traditional functions, the professional development of school leaders, teachers, and local administrative leaders is another mission of the NAER.

The China Educational Society (CES) is a non-profit organization that was established in 1930 in mainland China and moved its site to Taiwan in 1950. The CES is dedicated to holding annual academic conferences and publishing a yearbook every year. Due to political tensions with Mainland China, the CES cannot join the World Educational Research Association, but is the leading educational society in Taiwan. Without funding or influence on education research quality, the functions of the CES focus on connection with other academics societies with little authority in forming educational policy or research topics.

Compared with the mission and function of the MoST and Sinica, those of the NAER obviously focus more on practice and school business and less on education research quality. However, as the educational policy think-tank, the NAER does not consider that improving education research quality may enable education policy to be designed accurately or respond to the need for educational sites. In particular, because of the absence of an education research department at Academia Sinica, the value and status of education research has been lacking in official organizations. The function of the CES is limited to rewarding academic and service contribution without promoting educational research quality or forming cohesion. Thus, the position of education research in Taiwan is in the periphery compared with other social science fields.

\section{Research Policies in Taiwan}

The NSC and Academic Sinica both guide the policy of academic research trends in Taiwan, but the NSC has a larger effect on education research compared with Academic Sinica. According to the development strategy presented in the 2000 White Paper on the Development of the Humanities and Social Sciences, the planning and implementation of administrative research encompass a number of points to strengthen the academic research foundation. Relative to the quality of academic research, the strategies include the following (NSC 2000, pp. 33-34):

a. Two measures were adopted to adjust methods implemented during the past decade, including establishing a journal rating system and integrating and expanding databases. The NSC further encourages domestic journals to join large international databases to produce domestic research consistent with international trends.

b. Establishment of Taiwan Humanities Citation Index (THCI) and Taiwan Social Science Citation Index (TSSCI) core databases that facilitate the retrieval and citation of articles from domestic journals.

c. Establishment of a specialized book writing program, book review system, and book publishing assistance to help authors wishing to publish specialized books.

Knowledge is a key factor of production in any future society. Specifically, in the global knowledge-based economy era of the twenty-first century, nations that have invested resources in research and development and innovation could achieve a nationwide competitive advantage. As a member of global nations, Taiwan certainly cannot afford to disregard the trend of international competitiveness. International competitiveness in higher education in Taiwan, which is affected by globalization, marketization, and standardization, has been sought since the 1990s (Chou 2012; Chou et al. 2013). Coupled with the establishment of an academic evaluation mechanism in White Paper on the Development of the Humanities and Social Sciences of 2000, academic research quality was exacerbated by higher education from the perspective of publishing quantity. Furthermore, the Top University Plan of 2006, a five-year NT\$5-billion fund for higher education academic research released by the Ministry of Education, promotes calculating a reward based on the number of articles published in the Science Citation Index, 
Social Science Citation Index (SSCI), and Arts and Humanities Citation Index. Since the implementation of university evaluation, a single indicator forms the basis of assessment of knowledge production for the humanities, social sciences, and natural sciences. The humanities and social sciences journal rating system and journal database, such as the TSSCI, facilitate education and help academic researchers accumulate their number of journal articles (Chou, $\mathrm{Wu}$, and $\mathrm{Hu}$ 2011). Ying-hwa Chang, in his outgoing speech as the President of the Taiwanese Sociological Association of 19982000 , mentioned that, during the process of increasing their academic human resources, whether the academic has a substantial accumulation, the increase of cumulative ability contributes to the understanding of the social structure and social change. Do Taiwanese sociologists occasionally engage in self-assessment? How can a certain quality of research results be rendered through appropriate publishing? Scholars are facing a common issue. Such a problem is not only of significance to the research, but also the evaluation system of individual and overall academic standards, thereby affecting personal academic career job promotion (Chang, Hwang, and $\mathrm{Lu}$ 2000).

The Taiwanese government approved the well-articulated White Paper on Science and Technology (2011-2014) in December 2010. The vision of this white paper is that Taiwan will become a global leader in green energy technology and intelligent living by 2020 . Eight development strategies were formulated to address four major topics: science, economy, social welfare, and the environment. The specific strategies are as follows (NSC 2010, pp. 52-59):

1. Fully utilize technology talent to develop unlimited knowledge value.

2. Improve academic research quality and facilitate industry-academia collaboration.

3. Establish a global innovation center and strengthen niche industrial clusters.

4. Innovate healthy living technology and develop emerging smart industries.

5. Integrate disaster prevention and relief technology and increase the wellbeing and safety of people.

6. Combine technology with the humanities and enhance smart national soft power.

7. Loosen the restrictive legal system and strengthen policy foresight.

8. Innovate sustainable energy technology and construct a green low-carbon environment.

The joint efforts of government agencies in integrating S\&T achievements, outstanding talent, and industrial strength are expected to encourage the development of innovative industry and provide citizens with a smart living environment that is safe, healthy, convenient, comfortable, and energy efficient, in addition to the highest weighted economic rate of returns (NSC 2011b). Although education research has a close relationship with life, it is not the focus of the government research policy in the White Paper. Because education research is closely connected to the welfare of citizens, the goal of education research regarding the public good, the quality of education research must play an essential role in education practice and improving the progress of S\&T.

Education and sociology, both belonging to the humanities and social sciences, are facing the problem as well. Publication can gain award, promotion, and higher position in rating system excessively close to the significance of academic research do not guarantee to reveal the practice in reality. Escaping the research policy on academic quality as science and technology requests, as well as for education research, is difficult. The SSCI, reward-based evaluation, and knowledge production discourage the attitude of education researchers toward conducting research.

\section{Research Performance Evaluation in Taiwan}

As part of the social sciences field, education research has the same problem of focusing the "spotlight on the natural sciences but neglect[ing] the humanities and social sciences," which remains the unmistakable trend in Taiwan when considering the contribution to society (NSC 2000, p. 21). The value of education research should connect theory and practice and improve education. However, education research is affected by international academic competitiveness and emphasis on publication quantity over quality trend. How to promote quality has become a key issue in balancing research productivity and quality.

Since the University Act of 1994 in Taiwan, universities have implemented four ranks: instructor, assistant professor, associate professor, and professor. Since 2000, some universities have launched a faculty review of research productivity for faculty remaining at the university (Tien 2007). The trend of promoting the number of publications in international journals leads to the following trends in Taiwan:

First, publishing papers in English has been encouraged. Academic articles and books published in Chinese no longer offer a competitive advantage. In the social sciences, fewer articles are published compared with the engineering and natural sciences, and fewer books compared with the humanities (Tien 2008). Specifically, one book published in Chinese has a greater impact on promotion compared with publishing an article. Publishing one book in 1.89 years is approximately equal to publishing 3.26 articles in 0.58 years. However, the number of research publications still 
serves as a substantial predictor of the chances of receiving a promotion. The faculty promotion system in Taiwan deserves credit for rewarding faculty research productivity (Huang 2005; Tien 2007b). There was no productivity difference between assistant professors and associate professors (Tien and Blackburn 1996). Therefore, publishing a book is rarely the strategy for promotion in Taiwan, and the number of published books has decreased in the humanities and social science fields (Sinica 2013). Unless the promotion is awarded in the following year (Tien 2000), most faculties cannot publish a book every year.

Second, to increase the acceptance rate of contribution, international topics have become mainstream, but the relative domestic topics have not been taken seriously. Regarding citation, Chang, Hwang, and $\mathrm{Lu}$ (2000) indicated that Taiwanese researchers reference only a few articles in journals at an average of more than 1.5 times, and most average less than one time. The low citation rate among Taiwanese researchers reflects that the authors' academic accumulation is insufficient and that the mechanisms of academic participation and dialogue are lacking in Taiwan (Chang 2000), thus creating a short-term speculative academic atmosphere (Sinica 2013). In addition, $\mathrm{Su}$ (2004) reported that the phenomenon of polarizing a local academic community into "English" and "Chinese" clusters in sociological disciplines indicates the challenges of transforming and transferring paradigm-specific skills into a local context. Because of the lack of Chinese literature accumulation and interaction by local researchers, a large amount of knowledge is based on international research results (Huang 2005); thus, they have become obstacles to the development of indigenous research.

Third, because submission is mainly targeted to foreign English journals, particularly journals listed in the SSCI, government and university awards focus on the number of articles published rather than the quality of the article. The academic reward system consists of four categories of reward including: institutional salary, nonmaterial rewards of personal satisfaction, promotion to a higher rank, and optional access to career advancement in administration (Chou 1993; Tuckman 1979). The system is intended to be fair and objective regarding the fixed salary framework, and equal opportunity for employment and promotion is regulated by the government in Taiwan (Chou 1993). However, since the THCI and TSSCI databases were developed in 2000, the published quantity in the THCI, TSSCI, or SSCI become the core academic evaluation system in Taiwan for assessing research quality. This orientation causes some problems such as a high rejection rate by journals in the TSSCI, vicious reviews, an unfair review system, emphasis on personal relationships to facilitate promotion, a lack of accumulated research, a disregard of local practice reform, and a misunderstanding of how citation or impact factor equals research quality (Chou 2011; Huang 2005; Hwang 2010; Hwang and Tzeng 2008; Su 2004; Wang 2005;
Yeh 2005; Yeh and Chen 1998). This reveals that research performance is evaluated according to the amount of research productivity based on the standard of academic awards and promotion (Tien 2000). However, the faculty motivation to conduct research is affected by research value and research effort (positively), as well as teaching load (negatively) (Hardré, Beesley, Miller, and Pace 2011; Wang 2005). Soliman and Soliman (1997) mentioned that universities have shifted toward a research orientation since World War II. Research has been regarded as more prestigious than instruction and valued more in all higher education institutions. Research and publications have received increased attention and government support as an imperative for national development. Therefore, this has motivated the publishing press to direct the attention of education researchers more toward academic work and less on teaching practice.

Sufficient research equipment and abundant high-quality human resources are undoubtedly the foundation for academic excellence. However, the government's full support is required to improve the overall academic research environment, which would enable improving academic research quality. These are prerequisites for the development of original and prospective academic research fields that would promote industrial development and facilitate economic prosperity (NSC 2011b). However, regarding the direction to sound human wellbeing and enhance a high quality of life, higher education has created the aforementioned problem in the context of international academic competitiveness and publication volume in Taiwan. The problem is that, under the pressures of budget constraints, higher education leaders face the challenge of encouraging the research vitality of their faculties toward attaining academic prestige.

\section{Discussion}

Table 1 presents a comparison of the education organization, research policies, and research performance evaluation in Taiwan as well as problems in education research. First, because natural and social sciences differ fundamentally, searching the outcomes under rigorous control is difficult in the social sciences. It's hard to define causality for the complicate factors on social events. However, the government's full support is required to improve the overall academic research environment, which would enable enhancing academic research quality (Academia Sinica 2013). Whether education research is focused less on the official organization or research policy, an education division was not established in Academia Sinica and it provides funding only for education research in the MoST. The NAER's missions focus more on practice and school business than research. The function of the nongovernmental education society, the CES, is limited. Education research for improving the educational system and social wellbeing and as the foundation of na- 
tional strength is critical, but the status and value of education research compared with natural sciences in producing knowledge are disregarded in Taiwan. Without support from the government in establishing an official organization, how education research quality can be promoted to fit the needs of the education system is a topic to discuss because the NAER has only recently started operation and the CES's function is limited.

Second, because of the research policy, researchers who pursue published articles in accumulation disregard the importance of higher education personnel training. Education research is subject to less rigorous control. When the reward, promotion, and rating system produce linkage relationships, escaping the attitude toward competitiveness is difficult for education researchers.

Table 1. Education Organization, Research Policy, and Research Performance Evaluation in Taiwan

\begin{tabular}{|c|c|c|c|}
\hline Dimensions & $\begin{array}{c}\text { Education } \\
\text { Organization }\end{array}$ & $\begin{array}{l}\text { Research } \\
\text { Policies }\end{array}$ & $\begin{array}{c}\text { Research Perfor- } \\
\text { mance Evaluation }\end{array}$ \\
\hline $\begin{array}{l}\text { Goal in } \\
\text { Taiwan }\end{array}$ & $\begin{array}{l}\text { 1. Promotes the } \\
\text { development of } \\
\text { science and tech- } \\
\text { nology } \\
\text { 2. Offers excellent } \\
\text { policy advice } \\
\text { 3. Promotes a } \\
\text { happy life }\end{array}$ & $\begin{array}{l}\text { 1. Encourage do- } \\
\text { mestic journals to } \\
\text { join large interna- } \\
\text { tional databases } \\
\text { 2. Establishment } \\
\text { of THCI and } \\
\text { TSSCI core data- } \\
\text { bases } \\
\text { 3. Establishment } \\
\text { of a book writing } \\
\text { program, book re- } \\
\text { view system, and } \\
\text { book publishing } \\
\text { assistance }\end{array}$ & $\begin{array}{l}\text { 1. Encourages pa- } \\
\text { pers published in } \\
\text { English to increase } \\
\text { the acceptance rate } \\
\text { of contributions } \\
\text { 2. International } \\
\text { topics became } \\
\text { mainstream } \\
\text { 3. Government and } \\
\text { university awards } \\
\text { focus on the num- } \\
\text { ber of articles pub- } \\
\text { lished }\end{array}$ \\
\hline Th & $\begin{array}{l}\text { 1. NAER ignores } \\
\text { the improvement } \\
\text { of education re- } \\
\text { search quality } \\
\text { 2. The CES's func- } \\
\text { tion is limited }\end{array}$ & $\begin{array}{l}\text { 1. Operate from } \\
\text { the perspective of } \\
\text { publishing quan- } \\
\text { tity instead of arti- } \\
\text { cle quality } \\
\text { 2. Calculate the re- } \\
\text { ward based on the } \\
\text { number of articles } \\
\text { published } \\
\text { 3. Single indicator } \\
\text { forms the basis of } \\
\text { assessment on } \\
\text { knowledge pro- } \\
\text { duction }\end{array}$ & $\begin{array}{l}\text { 1. Spotlight on nat- } \\
\text { ural sciences, but } \\
\text { neglects the hu- } \\
\text { manities and social } \\
\text { sciences } \\
\text { 2. Lacks Chinese } \\
\text { literature accumu- } \\
\text { lation } \\
\text { 3. Disregards the } \\
\text { importance of } \\
\text { higher education } \\
\text { teaching practice } \\
\text { and personnel } \\
\text { training }\end{array}$ \\
\hline
\end{tabular}

Source: By the Author.

The knowledge production rule in the natural sciences is the same as that in the social sciences. Although the Academia Sinica (2013) clearly stated that a single indicator in the natural and social sciences prevented research outcomes from responding to national development and social needs, what indicators or rules in education research that can win the trust of the community must still be established? As a discipline of social science, knowledge production rule on the nature of education research transforms into an important issue for the education research community to form.

Finally, regarding the system for evaluating research performance, the rules of the rewards game produce an interlocking symbolic position to compete with economic capital. When a scholar searches for the symbolic position of academic status, following the quality standards expressing the competence of do research turns into the main principle instead of enhance a better life for human being. Most of their papers are then in English and less in Chinese, more international and fewer indigenous topics are researched, and more journal articles and fewer books are published. Therefore, the contributions to educational problems or systems of those works on international topics written in English and published in journals require in-depth thinking. Education research differs from research in the natural sciences that can be conducted under rigorous control or show an immediately apparent effect of improvement. By contrast, education research quality should focus on substance and accumulating research over the long term. The quality standards of evaluating research performance are quite unfair to education researchers regarding the competition of the rewards game. Without an official or nonprofit organization, education research communities must determine how to survive in the academic rewards system.

Regarding Taiwan's academic research environment, education research follows the global competition trend. With little support from research organizations, research policy, and performance standards, the education research community is a long way from cohesively finding its own definition of academic quality and reward systems.

\section{Conclusions}

The results of this study suggest that many questions remain unanswered. The costs of research, institutions of higher education competing for high-quality faculty, and the academic rewards funding problem surrounding research faculty productivity and research quality have been debated. Education research, as a category of the humanities and social sciences, is also debated. Specifically, education as a cornerstone for the welfare of people, how the result of education research can improve the lives of people, implementing a favorable policy for students, improving practice, and the quality of education research will determine its role and status in the field of research. Part of the relative value of research productivity and research quality regards the faculty tasks and institutional mission of higher education as well as the value to an individual and society. The other part is that the individual can earn a higher rank and re- 
ward for high productivity (Hardré et al. 2011). The short-term immediate and quantifiable productivity, called "evidence" in Hardré et al. (2011), should not be considered as the whole value of research, particularly compared with the highest quality and most enduring contributing research.

However, the established review system of academic research can increase the self-confidence of the academic community and contribute to the mutual respect of academic colleagues. Throughout the process of the reciprocal cycle of the review system, education researchers can develop additional empirical studies to construct rational writings to contribute to the welfare of citizens. The review system should be designed to have a close relationship with the incentive system, including the reward, promotion, and funding of external incentives in the academic community. Although the incentive system is centralized by the government, the intrinsic rewards from knowledge creation and contributions to society and academia should also be encouraged. Developing an academic evaluation mechanism is key to promoting healthy competition.

\section{References}

Chang, Ying-Hwa. 2000. “Academic Publishing, Review and Academic Development: The Participant Observation from a Sociologist." Taiwanese Journal of Sociology 23: 1-23.

Chou, Chuing Prudence. 1993. "Gender Differences in the Academic Reward System: A Case Study of Faculty Income in Taiwan." Bulletin of Educational Psychology 16: 475-500.

Chou, Chuing Prudence. 2009. "University to Establish the Need for Indicators of Humanities and Social Sciences." Science Monthly 473: 2-3.

Chou, Chuing Prudence. 2012. "The Urgency for University to Establish the Indicators in Humanities and Social Sciences." Taiwan Education Review 1 (6): 21-22.

Chou, Chuing Prudence, Hsiao-Fang Lin, and Yun-Ju Chiu. 2013. "The Impact of SSCI and SCI on Taiwan's Academy: An Outcry for Fair Play." Asia Pacific Education Review 14 (1): 2331.

Chou, Chuing Prudence, Rong-Feng Wu, and Zhu-Hui Hu. 2011. "The Impact of SSCI on Taiwan's Academic Evaluation in the Humanities and Social Sciences: A Case Study of NCCU. Journal of Comparative Education 70: 31-56.

Chou, Ping. 2011. "The Discourse and Counter-discourse formation of the University Evaluation in Documents Since 1975." Formosan Education and Society 23: 79-125.

Desimone, Laura M., and Kerstin C. Le Floch. 2004. "Are We Asking the Right Questions? Using Cognitive Interviews to
Improve Surveys in Education Research." Educational Evaluation and Policy Analysis 26 (1): 1-22.

Featherstone, Mike. 1993. "Global and Local Cultures." In Mapping the Futures: Local Cultures, Global Change, edited by John Bird (pp. 169-187). London, UK: Routledge.

Hardré, Patricia L., Andrea. D. Beesley, Raymond. L. Miller, and Terry M. Pace. 2011. "Faculty Motivation To Do Research: Across Disciplines in Research Intensive Universities." The Journal of the Professoriate 5 (1): 35-69.

Hazelkorn, Eellen. 2009. Impact of Global Rankings on Higher Education Research and the Production of Knowledge. UNESCO Forum on Higher Education, Research and Knowledge. Occasional Paper No. 18. Paris: UNESCO.

Huang, Hou-Ming. 2005. "SSCI, TSSCI, and the Academic Evaluation System of Social Sciences in Taiwan." Journal of Library and Information Science 31 (1): 34-44.

Hwang, Yih-Jyh, and Shih-Jay Tzeng. 2008. "The Editorial Systems, Vicious Reviewers, and Reviewer's Ethics Behind the High Rejection Rate of Taiwan Scholarly Educational Journals." NTTU Educational Research Journal 19 (2): 183-196.

Hwang, Yih-Jyh. 2010. “An Examination on the Editing and Review Mechanism of Taiwan Educational Journals: How to Achieve Educationalists' Collective Growth in the Benign Academic Interaction?" Journal of Education Studies 44 (1): 1-20.

National Science Council (NSC). 2000. White Paper on the Development of the Humanities and Social Sciences. Taipei, Taiwan: NSC.

NSC. 2010. White Paper on Science and Technology. Retrieved from http://www.most.gov.tw/public/Attachment/18231893271.pdf

NSC. 2011a. White Paper on Science and Technology (Digest Version). Retrieved from http://www.most.gov.tw/public/Attachment/192010415071.pdf

NSC. 2011b. Yearbook of Science and Technology, Taiwan, ROC, 2011. Taipei, Taiwan: National Applied Research Laboratories.

Sinica. 2013. Recommendations on Higher Education and Science and Technology Policy. Taipei, Taiwan: Sinica.

Soliman, Izabel, and Hani Soliman. 1997. "Academic Workload and Quality." Assessment \& Evaluation in Higher Education 22 (2): 135-158.

Su, Kuo- Hsien. 2004. "Social Production of Sociological Knowledge: Invisible Colleges Among Sociologists in Taiwan.” Taiwanese Sociology 8: 133-192.

Tien, Flora F., and Robert T. Blackburn. 1996. "Faculty Rank System, Research Motivation, and Faculty Research Productivity: Measure Refinement and Theory Testing." The Journal of Higher Education 67 (1): 2-22. 
Tien, Flora F. 2000. "To What Degree Does the Desire for Promotion Motivate Faculty to Perform Research? Testing the Expectancy Theory." Research in Higher Education 41 (6): 723-752.

Tien, Flora F. 2007a. "Faculty Research Behavior and Career Incentives: The Case of Taiwan." International Journal of Educational Development 27 (1): 4-14.

Tien, Flora. F. 2007b. "To What Degree Does the Promotion System Reward Faculty Research Productivity?" British Journal of Sociology of Education 28 (1): 105-123.

Tien, Flora F. 2008. "What Kind of Faculty are Motivated to Perform Research By the Desire for Promotion? Higher Education 55 (1): 17-32.

Tuckman, Howard P. 1979. "The Academic Reward Structure in American Higher Education." In Academic Rewards in Higher Education, edited by Darrell R. Lewis and William E. Becker (pp. 165-190). Cambridge, MA: Ballinger Publishing Company.

Wang, Mei-Ling. 2005. "University Research Assessment and Citation Analysis." Journal of Library and Information Science 31(1): 5-13.

Yeh, Hsiu-Jen, and Chen, Kuanjeng. 1998. "The Status and Development of Research in Sociology and Social Work." Taiwanese Journal of Sociology 21: 21-57.

Yeh, Nei-Ching. 2005. "Impact Factor: A Controversial Way of Journal and Research Quality Measurement." Journal of Library and Information Science 31 (1): 70-78. 